\title{
Original paper \\ Mantle lithosphere control of crustal tectonics and magmatism of the western Ohře (Eger) Rift
}

\author{
Vladislav BABUŠKA*, Jaroslava PLOMEROVÁ \\ Geophysical Institute, Academy of Sciences of the Czech Republic, Bočni II/1401, 14131 Prague 4, Czech Republic; babuska@ig.cas.cz \\ * Corresponding author
}

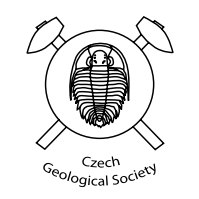

This paper summarizes our recent research on the relationship between tectonics of the mantle lithosphere and of the upper crust in the western Bohemian Massif. The rejuvenated Variscan junction of three mantle domains, the Saxothuringian, Moldanubian and Teplá-Barrandian, delimited by different orientation of seismic anisotropy reflecting a consistent fossil olivine orientation and belonging to originally separated microplates, plays important role in the crustal architecture of the region. The crust above the mantle junction is the most active part of the BM characterized by periodic earthquake swarms and mofettes emitting gases of mantle origin. Detected offsets of surface boundaries of the three units from their mantle counterparts indicate a detachment of the rigid upper crust from the mantle lithosphere. Locations of major tectonic features like the Ohře (Eger) Rift, the West Bohemian Shear Zone and the Mariánské Lázně Fault were probably predisposed by the boundaries of the mantle lithosphere domains. We have suggested that the sublithospheric mantle of the western BM acted as a major provider for heat and partial melts and the Variscan mantle boundaries served as magma conduits for the late-orogenic granitic magmatism and, after their rejuvenation, also for the Cenozoic volcanism. Similarly, the boundaries may have pre-determined the subsequent locations of sedimentary basins. It is possible that also in other regions some of these so called intra-plate phenomena can be related to partly healed up and later rejuvenated microplate boundaries.

List of abbreviations: BM - Bohemian Massif, BOHEMA - International project "BOhemian Massif HEterogeneity and Anisotropy", BP - Bor Pluton, CHB - Cheb Basin, DEKORP Deutsches Kontinentales Reflexionsseismisches Programm, DP - Doupovské hory Mts., DU - Dyleň Unit, ECC - Erzgebirge (Krušné hory) Crystalline Complex, ECRIS - European Cenozoic Rift System, ER - Ohře (Eger) Rift, HSU - Horní Slavkov Unit, KH - Komorní Hůrka, KHF - Krušné Hory (Erzgebirge) Fault, KU - Kladská Unit, KVP - Karlovy Vary Pluton, MD - Moldanubian Unit, MLC - Mariánské Lázně Complex, MLF - Mariánské Lázně Fault, PF - Plesná Fault, SB - Sokolov Basin, SP - Smrčiny (Fichtelgebirge) Pluton, ST - Saxothuringian Unit, T-junction - "triple" junction of the ST/TB/MD mantle lithospheres, TB - Teplá-Barrandian Unit, TCC - Teplá Crystalline Complex, TP - Tirschenreuth Pluton, WBSZ - West Bohemian Shear Zone, ZEV - Zone of Erbendorf-Vohenstrauss, ZH - Železná Hůrka, ŽP - Žandov (also Lesný-Lysina or Kynžvart) Pluton.

Keywords: mantle lithosphere domains, seismic anisotropy, Ohře (Eger) Rift, mantle sutures, control of crust architecture Received: 7 April 2010; accepted: 8 September 2010; handling editor: J. Málek

\section{Introduction}

The area of our study - the western Ohře (Eger) Rift (ER) - is a part of the European Cenozoic Rift System (ECRIS, Prodehl et al. 1995). This system of graben structures and volcanic fields spreads over a distance of about $1000 \mathrm{~km}$, including the French Massif Central, the Upper Rhine Graben, the Eifel, the North Hessian Depression, the Vogelsberg, the Ohře (Eger) Rift and the Pannonian Basin. The widespread rifting and associated volcanism in the foreland of the Alpine orogen is usually related to the effects of Alpine collision (e.g. Ziegler 1992). On the other hand, Granet et al. (1995) suggested that the ECRIS may have a common source of a 'plume-like' volcanism in the mantle, manifested by the existence of 'baby-plumes' beneath the Variscan massifs. Teleseismic tomography studies have imaged such relatively narrow plumes beneath the French Massif Central (Granet et al. 1995) and the Eifel (Ritter et al. 2001).

From the point of geodynamics, the western ER is the most active part of the Bohemian Massif (BM). Active tectonics is primarily manifested by Cenozoic volcanism (Ulrych et al. 2000), gas emanations containing high proportions of mantle-derived $\mathrm{CO}_{2}$ and $\mathrm{He}$ (Weinlich et al. 1999), as well as by the periodic occurrence of shallow earthquake swarms (Horálek and Fischer 2008) and neotectonic crustal movements (Bankwitz et al. 2003; Schunk et al. 2005). The question of a possible source of mantle fluids is important namely in relation to the recent increase of ${ }^{3} \mathrm{He} /{ }^{4} \mathrm{He}$ ratios observed by Bräuer et al. (2005). The authors interpreted the observation as an evidence for ascending mantle-derived melt and as an indication of a possible future unrest in this presently inactive volcanic region. 
The concentration of various ongoing geodynamic phenomena in a small area of the western ER called for a study focused on the interaction between near-surface tectonics and geodynamic processes at depth. Geoscientists from 10 institutions in the Czech Republic, Germany and France cooperated within the BOHEMA project (BOhemian Massif HEterogeneity and Anisotropy, Babuška et al. 2003) to study the structure and dynamics of the lithosphere and asthenosphere of the western BM. Central to the BOHEMA project was a passive seismic experiment in 2001-2003, which provided important set of data for the high-resolution teleseismic tomography down to a depth of about $250 \mathrm{~km}$ and for a model of large-scale seismic anisotropy of the mantle lithosphere in the western BM (Plomerová et al. 2007; Babuška et al. 2008).

This paper summarizes major results on fabrics of the mantle lithosphere retrieved up to now from passive seismic experiment of the BOHEMA international project (Babuška et al. 2003). We have focused on the western ER above the junction of three mantle lithospheres, the Saxothuringian (ST), Moldanubian (MD) and the Teplá-Barrandian (TB) units, delimited by mapping their seismic anisotropy at the dense BOHEMA network of temporary stations (Plomerová et al. 2007; Babuška et al. 2008). Tectonics of the mantle lithosphere most probably predisposed formation of the western ER, affected paths for late Variscan and Cenozoic magmatism as well as the location of sedimentary basins. We coin the idea that it is important to look beneath the Moho discontinuity when we want to understand geodynamic processes recorded in tectonics and in magmatic products of the complex crustal structure. The paper does not have ambitions to solve a complicated tectonic development of the region and it does not present details of geophysical methods used to infer structure of the mantle lithosphere published elsewhere (see references to individual results). The paper aims at providing a review of seismological results on deep lithosphere structure of the region to contribute to a holistic view and better understanding of the coupling between tectonic processes near the surface and deepseated dynamics of the mantle lithosphere. Such approach is important for developing future models, which will realistically consider the entire lithosphere in tectonic history of the complex Variscan collision zone.

\section{Mantle investigations of the western Bohemian Massif by teleseismic methods}

Most of constrains on the upper mantle structure of the western BM come from teleseismic body waves travelling through the entire Earth and recorded at dense networks of stations in the region. Changes in seismic wave velocities, both with depth as well as laterally, are retrieved from deviations of the travel times of longitudinal $\mathrm{P}$ waves and from polarization of shear-waves. Deviations in seismic wave propagation relative to a radial Earth velocity reference model are exploited in seismic tomography resulting in isotropic images of the Earth interior. We also model a large-scale anisotropy (fabric) of the upper mantle by analysing directional variations of the P-wave travel times and polarization of shear waves (shear-wave splitting).

\subsection{Seismic tomography}

Plomerová et al. (2007) presented initial tomographic model of the upper mantle beneath the whole BM down to $250 \mathrm{~km}$, with variance improvement of $71 \%$ and the highest resolution in the western part of the massif. For this paper we selected velocity perturbations in three layers of the model comprising the mantle lithosphere beneath the BM along with two perpendicular vertical cross-sections (Fig. 1). Depth of the model depends on lateral size of the array of seismic stations and the resolution depends on a density of crossing rays within the investigated volume. Therefore, not only a sufficient amount of data, but also a good azimuthal and incidence angle coverage is needed. Data for the tomography (Pwave arrival times) were measured on the BOHEMA network recordings of more than 240 teleseismic earthquakes, which provided 13500 rays for the tomographic inversion, with a lateral resolution of about $20 \mathrm{~km}$ in the upper mantle.

The sufficient lateral resolution allowed searching for a hypothetical narrow ( $\sim 50 \mathrm{~km}$ in diameter) and vertical low-velocity anomaly beneath the ER, which would be similar to plumes found beneath the other Variscan massifs - the French Massif Central and the Eifel (Granet et al. 1995; Ritter et al. 2001). In general, velocity perturbations in the tomographic images (Fig. 1) are weak and correlate with large-scale tectonic features. But they did not image any distinct low-velocity heterogeneity down to $250 \mathrm{~km}$, which could be interpreted as a magma chamber or a mantle plume. There are weak negative perturbations in the mantle beneath the western part of the ER, which can be traced down to the bottom of the model. But they do not form any tube-like low-velocity heterogeneity, which could be associated with a narrow uprising plume below the rift at these depths. Moreover, this tomography, which is corrected for crustal effects, shows such well-resolved negative perturbations of comparable amplitudes also in other parts of the model (Fig. 1) though their resolution may be lower due to a lower number of stations. However, incorporating the stations in the eastern and southern BM is important for resolving the mantle down to $250 \mathrm{~km}$ below the ER. We interpret the negative perturbations in the western BM by 

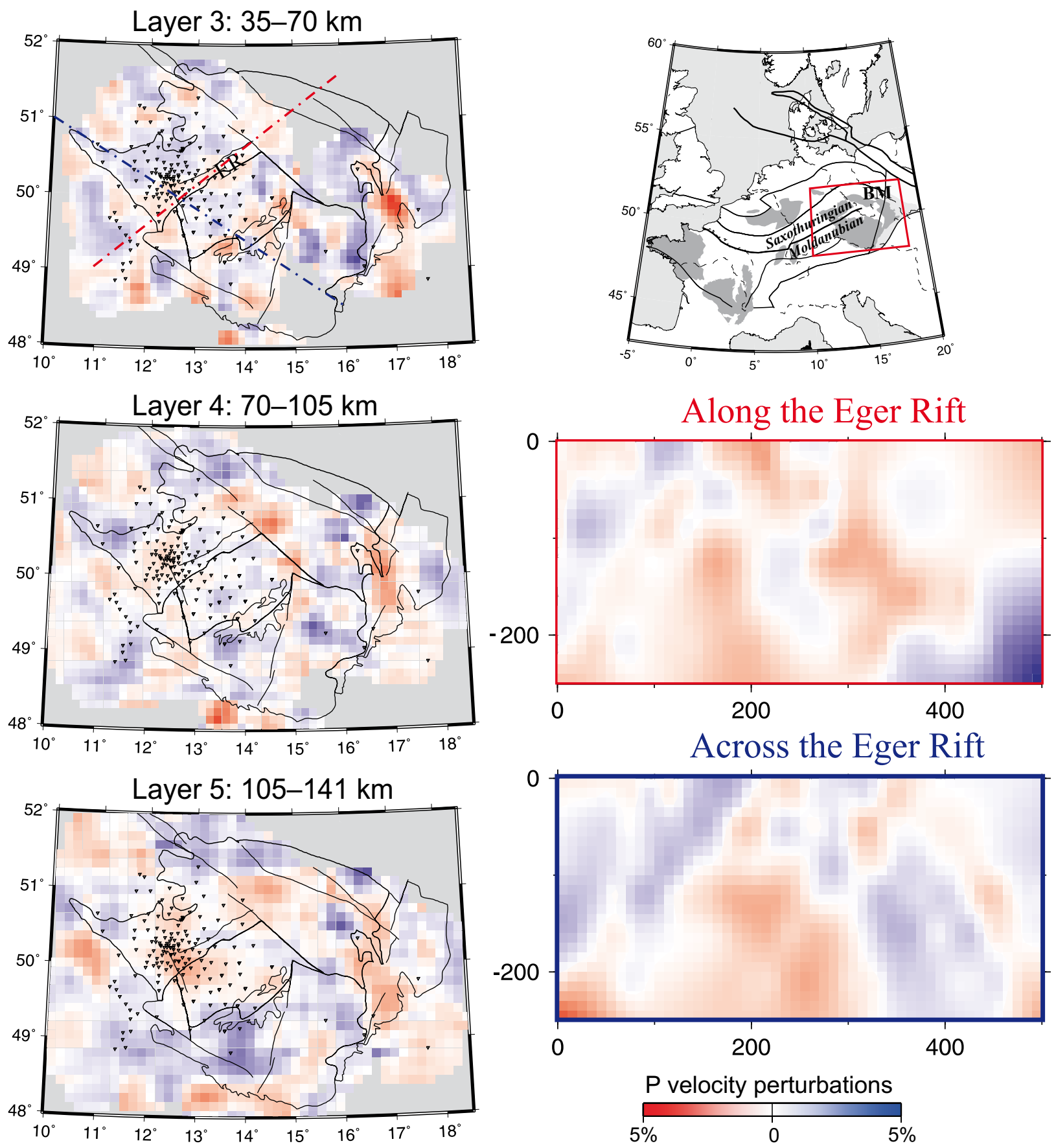

Fig. 1 Plane views of tomographic images of smoothed P-velocity perturbations in the lithosphere-asthenosphere system of the Bohemian Massif (BM) selected for three deep layers (left) from Plomerová et al. (2007) and projections of the seismic stations (triangles). Two vertical cross-sections (see Layer 3 for their location) through the velocity perturbation model (right) along and across the Ohře (Eger) Rift (ER) indicate the lithosphere thinning beneath the rift. Major Variscan massifs in central-western Europe are shaded (top right).

a lithosphere thinning along the whole ER and the positive perturbations in the southern BM by a lithosphere thickening to the south beneath the Moldanubian Unit.

To show velocity variations related to the ER, Plomerová et al. (2007) constructed two cross-sections through the velocity perturbation model - along and across the rift (Fig. 1). The low-velocity perturbations form a broader, ridge-parallel anomaly, which can be interpreted as an asthenosphere updoming (a lithosphere thinning), mapped there also, for instance by Babuška and Plomerová (2001) and derived by Heuer (2006) and Geissler et al. (2010) from receiver function studies. 


\subsection{Mapping of seismic anisotropy}

Seismic anisotropy provides key information to our understanding of tectonic fabric of the lithosphere-asthenosphere system (Babuška and Cara 1991). Thanks to systematic preferred orientation of olivine crystals and their elastic anisotropy, the mantle lithosphere exhibits a consistent large-scale seismic anisotropy of domains in dimensions of several hundred kilometres (Babuška and Plomerová 2006, for review) observed in directional variations of longitudinal-wave velocities and in shearwave splitting. Teleseismic shear-wave splitting, the analogy of the light birefringence, is generally considered as a proof of the upper mantle anisotropy, and represents the most common method to study the seismic anisotropy (see, e.g., Savage 1999, for review). The presence of seismic anisotropy, as an almost ubiquitous property of the mantle, is now documented by extensive sets of data from temporary arrays of seismic stations covering a large variety of tectonic settings. We use two methods to evaluate anisotropic parameters of body waves. Directional variations of the parameters we then invert to retrieve 3D anisotropic self-consistent models of the mantle lithosphere (Šílený and Plomerová 1996).

If seismic waves propagate through anisotropic media (Fig. 2), we record early arrivals (negative residuals) for waves propagating in high-velocity directions and delayed arrivals (positive residuals) for waves propagating in low-velocity directions. To show the spatial variations of relative $\mathrm{P}$ velocities and to study the P-velocity anisotropy, we construct for each station a P-residual sphere showing azimuth-incidence angle dependent terms (directional terms) of relative residuals in a lower hemisphere projection. All the calculations are related to a velocity mean - a directional mean which represents an isotropic velocity in the volume beneath a station. As the directional mean forms a reference level in each sphere, the P spheres can be compared easily, regardless of differences in the lithosphere thickness, which is the dominant high-velocity heterogeneity in the uppermost mantle and affects the station means. To reduce effects due to sediments and variable crustal thickness and velocities, we apply crustal corrections derived from results of deep seismic soundings and receiver function analysis in the first step of calculations, i.e., in computing the absolute $P$ residuals as differences between the observed travel time and the travel time calculated according to a reference radial Earth model. We have used the IASP91 Earth model (Kennett 1991). For details of the method we refer to, e.g., Babuška and Plomerová (1992).

Similarly to other regions, also in the BM we often observe the so-called 'bipolar' pattern of the P spheres, where negative directional terms consistently prevail in one half of the hemisphere, while positive ones dominate in the other half. Relating the early and delayed arrivals with the high- and low-velocity directions, we interpret such bipolar pattern in the $\mathrm{P}$ spheres as a result of propagation through a dipping olivine fabric of the mantle lithosphere and model them by peridotite aggregates with dipping foliations (b-axis models) or lineation (a-axis models; for details see Babuška et al. 2008).

The P-sphere patterns can be affected to some extent by a presence of crustal anisotropy and by a trade-off between the anisotropy and velocity heterogeneities. The trade-off makes it difficult to separate out the respective contributions and we can rely only on indirect indications. Sources of seismic anisotropy in the crust (cracks, bedding/lamination of sediments, foliation of metamorphic rocks) differ from the upper mantle anisotropy, caused mainly by a large-scale olivine preferred orientation in large volumes of relatively homogeneous fabrics. Smallsize (relative to seismic wavelengths) varying anisotropy in the crust behaves as a heterogeneous volume and, similarly to non-compensated small-size crustal heterogeneities (e.g., due to a varying density of rock complexes), can appear as localized singular distortion in otherwise smooth pattern of the P spheres. The smooth and consistent pattern of seismic anisotropy can extend laterally up to several hundreds kilometres. Its change is often linked with prominent tectonic sutures or dominant faults cutting the whole lithosphere (Babuška and Plomerová 2006). Different P-sphere patterns on both sides of a suture often turns to "no P pattern" right above a suture, as the waves sample both differently oriented fabrics. It would be difficult to explain sudden changes of the P-sphere pattern associated with prominent tectonic boundaries by velocity heterogeneities in the deep mantle. Such characteristics of the $\mathrm{P}$ spheres described above, along with geographical and back-azimuth variations of the shear-wave splitting, allow us to associate the directional velocity variations with seismic anisotropy of the mantle lithosphere.

Two shear waves propagate within an isotropic medium with identical velocity and no preferred polarization. When entering an anisotropic medium, such waves separate (split) into the fast and slow waves with polarizations in mutually perpendicular planes. Shear-wave splitting parameters - fast shear (S) wave polarization and delay time $(\delta \mathrm{t})$ of the slow $\mathrm{S}$ wave - reflect a strength, symmetry and axes orientation of the anisotropic medium. By analyzing lateral and azimuthal variations of the splitting parameters and by inverting these variations, jointly with $\mathrm{P}$ anisotropic parameters, we can model a lithosphere fabric. Joint inversion/interpretation of independent data (e.g., deviations in travel times, shear-wave splitting, surface-wave dispersions, receiver functions) reduces a set of potential models which could explain the observations and thus favour more realistic solutions (Fouch and Rondenay 2006; Vecsey et al. 2008). 


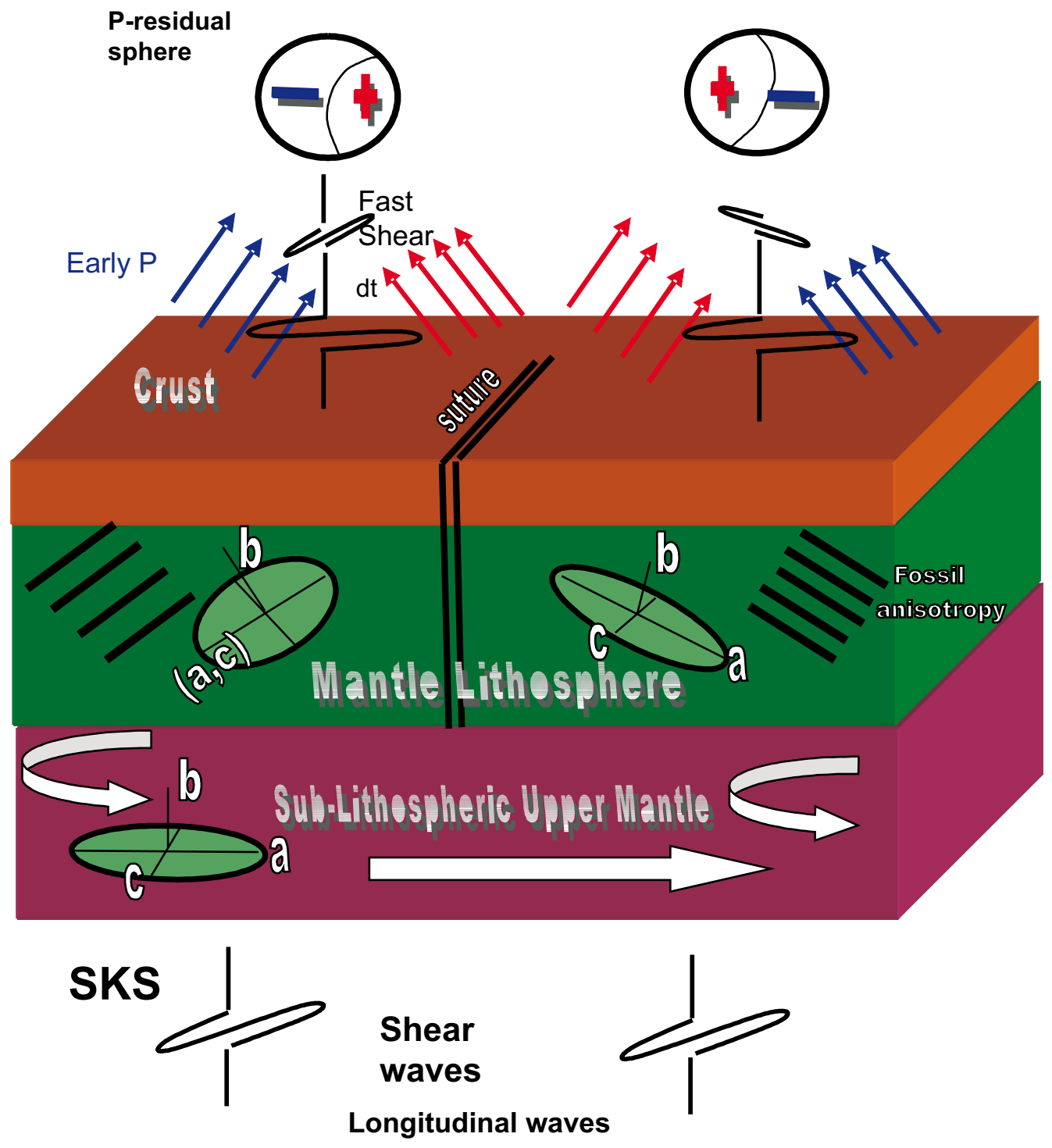

Fig. 2 Schematic block-diagram showing principles of the 3D modelling of seismic anisotropy from a directional dependence of relative residuals of longitudinal (P) waves and from shear-wave (SKS) splitting. Both types of waves arrive at seismic stations from teleseismic distances. Seismic anisotropy in the asthenosphere can be related to systematic orientation of olivine due to a slow sub-horizontal flow. Two domains of the mantle lithosphere, separated by a suture cutting the entire lithosphere, are characterized by differently oriented anisotropic fabrics approximated by olivine aggregates of hexagonal (left, $(a, c)$ is the plane of high $\mathrm{P}$ velocities), or orthorhombic symmetry (right, axis $a$ is the high-velocity direction). Strength of velocity anisotropy is derived from the fabric of peridotite xenoliths (see, e.g., Ben Ismail and Mainprice 1998). The anisotropy orientation and its symmetry are modelled by a joint inversion of body-wave anisotropic parameters. The diagrams above schematically show anisotropic parts of P residuals in a lower-hemisphere projection. Relative high-velocity directions (blue arrows) project as early P arrivals (negative residuals, blue) and relative low-velocity directions (red arrows) as delayed P-arrivals (positive residuals, red). The P residual is a difference between aa observed travel time and a theoretical travel time calculated for a standard radial Earth model.

Babuška et al. (2008) analysed splitting of shear-waves on recordings of about 130 earthquakes with magnitude larger than 5.6 at epicentral distances larger than $85^{\circ}$ with respect to the centre of the BOHEMA array. The selected waveforms have a large signal/noise ratio and well separated shear phases. The shear-wave splitting was evaluated with code SPLIT (Vecsey et al., 2008) based on a 3D approach by Šílený and Plomerová (1996). Shear- wave splitting analysis detected only small but systematic changes of the prevailingly $\mathrm{E}-\mathrm{W}$ fast split polarizations over the whole western BM with average delay times of $1.2 \mathrm{~s}$ (Fig. 3). On the other hand, the P-velocity anisotropy has recognized three distinctly different orientations of fabrics in the mantle lithosphere of the three tectonic units - the Saxothuringian (ST), Moldanubian (MD) and TepláBarrandian (TB) (Plomerová et al. 2007). The ST pattern 
Models with divergently dipping $(\boldsymbol{a}, \boldsymbol{c})$ foliations

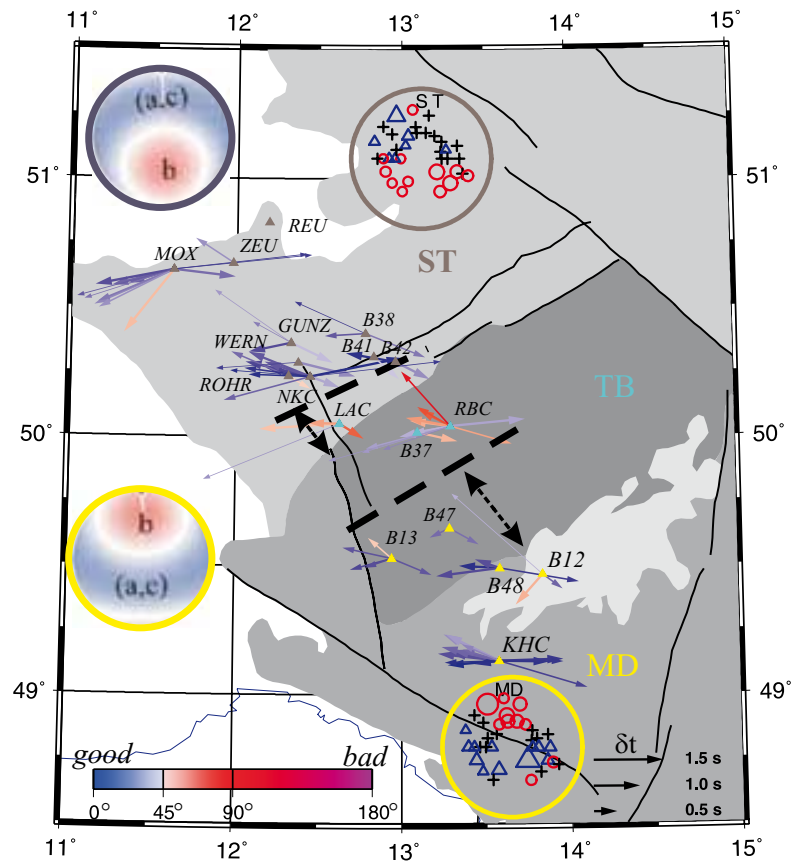

Model with dipping $\boldsymbol{a}$ lineation

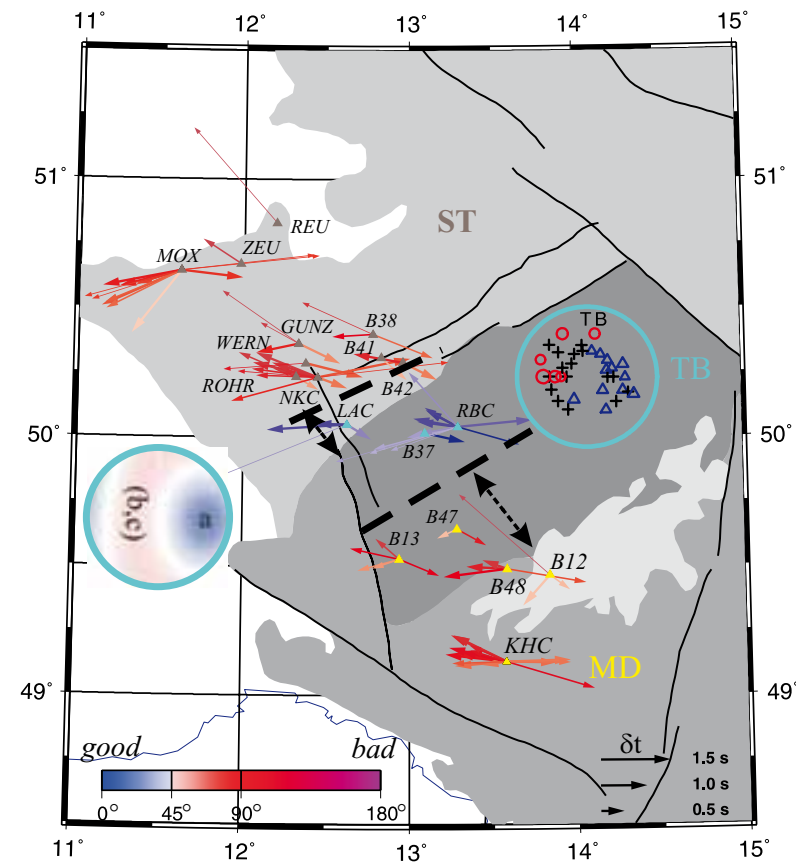

Fig. 3 Conformity of the observed and synthetic shear-wave splitting calculated for the aggregates represented by velocities in the lower hemisphere projection and by the symmetry axes. Orientations of the aggregates were retrieved by inversions of the P-residual spheres (the spheres with symbols, where red circles - positive terms of the relative residuals - mark the low-velocity directions of wave propagation and blue triangles - negative terms - stand for the high-velocity directions of propagation relative to a velocity mean. Black crosses mark directions with residual terms close to zero, in interval $(-0.1 \mathrm{~s}, 0.1 \mathrm{~s})$. The conformity is expressed as a difference between the observed and synthetic fast shear-wave polarization azimuths. The observed fast shear-wave azimuths $\Phi$ and split delay times $\delta$ t (thick arrows - good evaluations, thin arrows - fair evaluations), coloured according to the conformity, are shown for the broad-band stations (for details see Babuška et al. 2008). The orientations of the hexagonal $b$-axis model (left) explain well directional variations of the splitting within the Saxothuringian (ST) and Moldanubian (MD), while this symmetry fails to explain the splitting at stations located above the Teplá-Barrandian (TB) mantle lithosphere. On the other hand, the hexagonal $a$-axis model (right) fits the polarizations at the three TB stations, while it fails to model the observations at stations in the ST and MD. The dashed lines approximate the TB mantle domain boundaries, which are north-westerly shifted (dashed double arrows) relative to the crustal boundaries of the units and indicate a possible thrusting of the MD mantle lithosphere beneath the south-eastern rim of the TB.

exhibits the negative residuals for northern propagation directions, the MD pattern is characterized by negative residuals (relatively high-velocity directions) for southern propagation, and the TB pattern by negative residuals for waves arriving from NE-SE (Fig. 3). We have modelled fabrics of the mantle lithosphere of the three units by peridotite aggregates of hexagonal symmetry with easterly dipping lineations $a$ (TB) and divergently dipping foliations $(a, c)$ (to the $\mathrm{N}-\mathrm{NW}$ in the $\mathrm{ST}$, to the $\mathrm{S}-\mathrm{SW}$ in the MD). Such self-consistent 3D anisotropic models result from inversion and joint interpretation of the $\mathrm{P}$ residual spheres and shear-wave splitting synthetics. The resolved fabrics are compatible for the two independent datasets of anisotropic parameters (Babuška et al. 2008).

\section{Tectonic predisposition of the Ohře (Eger) Rift}

During the Variscan orogeny the lithosphere of the BM was assembled by collisions of independent blocks (e.g.,
Franke 2006), which apparently retained in the mantle lithosphere their olivine fabric that predated incorporation of these microplates into the Variscan Orogen (Babuška and Plomerová 2006). Moreover, during the post-orogenic re-equilibration of the lithosphere/asthenosphere system, the mantle lithosphere was not significantly thinned and thus preserved its olivine fabric. This is compatible with limited Mesozoic subsidence of the BM.

Most papers dealing with the process of rifting accept that tectonic forces are insufficient to disrupt continental lithosphere, unless the lithosphere has been weakened prior to rifting (e.g., Bailey and Wooley 1999). Also the essentially Miocene ER is superimposed on the Variscan suture zone between the ST in the north and the TB/ MD in the south. This suture has been identified on the basis of both geological (Jindřich 1971; Kopecký 1978; Franke et al. 1995; Zulauf et al. 2002) and geophysical (Krawczyk et al. 2000; Švancara et al. 2000; Šrámek 2001) data. The very complex crustal structure beneath the westernmost part of the graben structure of the ER is reflected in a large variability of interpretations and 
Fig. 4 Three mantle lithosphere domains defined by different orientation of seismic anisotropy and their transition (colour provinces), along with the contours of the crystalline basement of the Saxothuringian (ST), Moldanubian (MD) and Teplá-Barrandian (TB) tectonic units. Profile A-B locates the cross-section in Fig. 5. The inset of the European Cenozoic Rift System (ECRIS) is from Prodehl et al. (1995). For additional abbreviations see caption to Fig. 6.

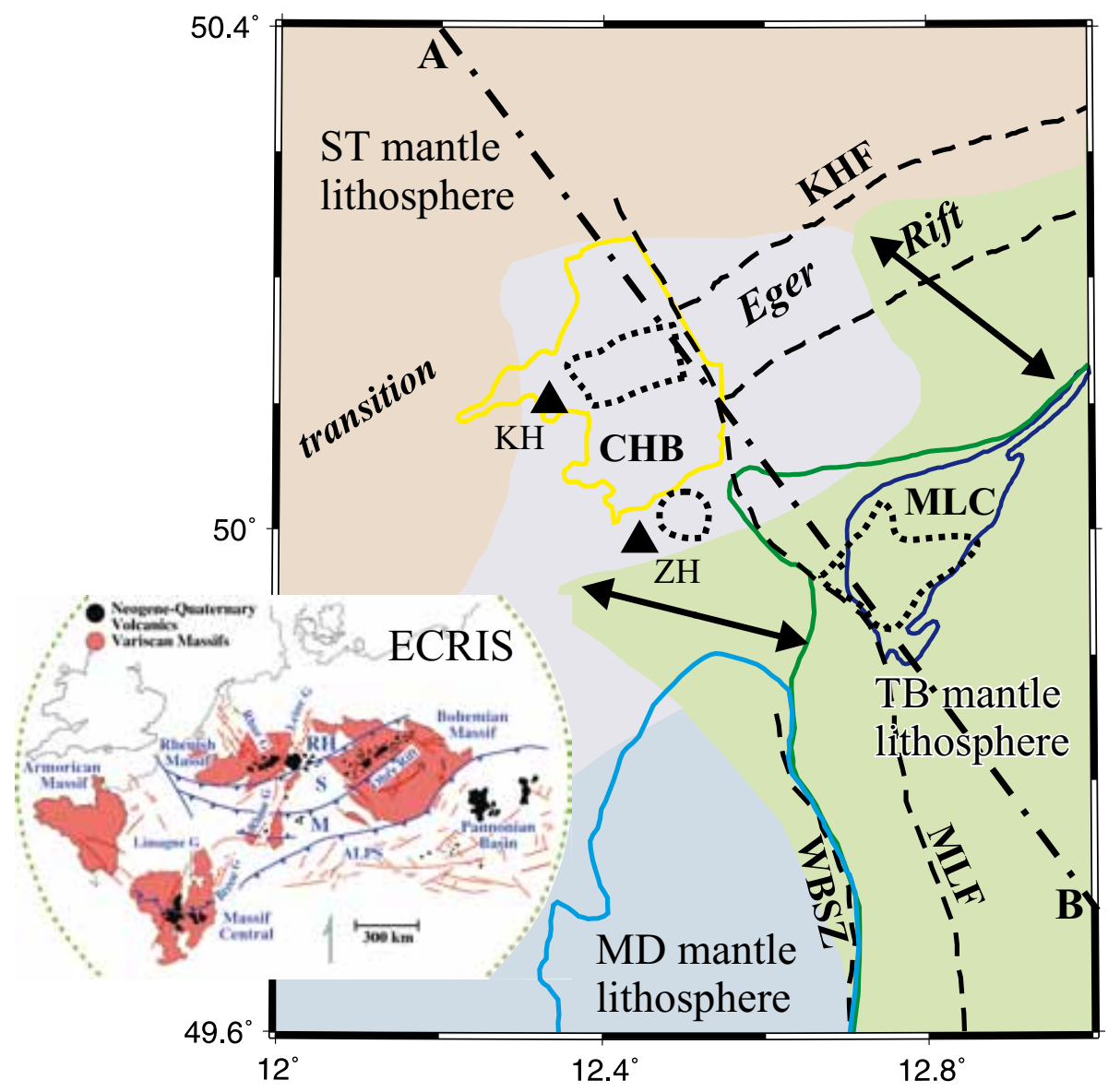

in changes of Moho depths which vary (depending on the used method due to their different sensitivity on various physical parameters) from c. $27 \mathrm{~km}$ beneath the CHB (Geissler et al. 2005; Heuer 2006) to c. $33 \mathrm{~km}$ (Hrubcová et al. 2005), or even $35 \mathrm{~km}$ in the near surroundings (Grad et al. 2008). To explain the complexity of the crust, already Tomek et al. (1997) suggested on the basis of the 9HR deep seismic reflection profile that the middle and lower crust of the Saxothuringian Terrane is thrust beneath the TB crust. Positions of the boundaries of the ST, TB and MD units mapped on the surface and

Fig. 5 Lithosphere cross-section along Profile A-B (see Figs 4 and 6 for location) showing three mantle lithosphere fabrics derived from seismic anisotropy. Anisotropic structure of the mantle lithospheres (Plomerová et al. 1998; Babuška et al. 2008) is approximated by peridotite aggregates with strength of $\mathrm{P}$ anisotropy $\sim 6 \%$ and with the high-velocity $a$ axis dipping to the $\mathrm{E}$ (in the TB), or with the high-velocity $(a, c)$ foliation plane dipping to the NNW (in the ST), or to the S (in the $\mathrm{MD})$. The velocity distribution is presented in polar projections of the lower hemisphere, blue - high velocity directions $\left(\max . \mathrm{v}_{\mathrm{p}}=8.6 \mathrm{~km} / \mathrm{s}\right)$, red - low velocity directions (min. $\left.\mathrm{v}_{\mathrm{p}}=7.8 \mathrm{~km} / \mathrm{s}\right)$. KHF - Krušné Hory Fault, PMS - Paleozoic Metasediments, ECC - Erzgebirge Crystalline Complex, KU - Kladská Unit, MLC - Mariánské Lázně Complex. Underthrusting of the ST crust is according to Tomek et al. (1997) and the Bouguer anomalies are after Šrámek (2001). their upper-mantle equivalents, as identified by different directional dependences of P-wave velocities (Fig. 4) indicate a detachment of the rigid upper crust from the lower crust and the mantle lithosphere (Plomerová et al. 2007) and a very complicated geometry of the boundaries of the units (Babuška and Plomerová 2008).

Occurrences of Cenozoic sediments and volcanics in Bavaria (e.g., Kämpf et al. 2005) clearly indicate a

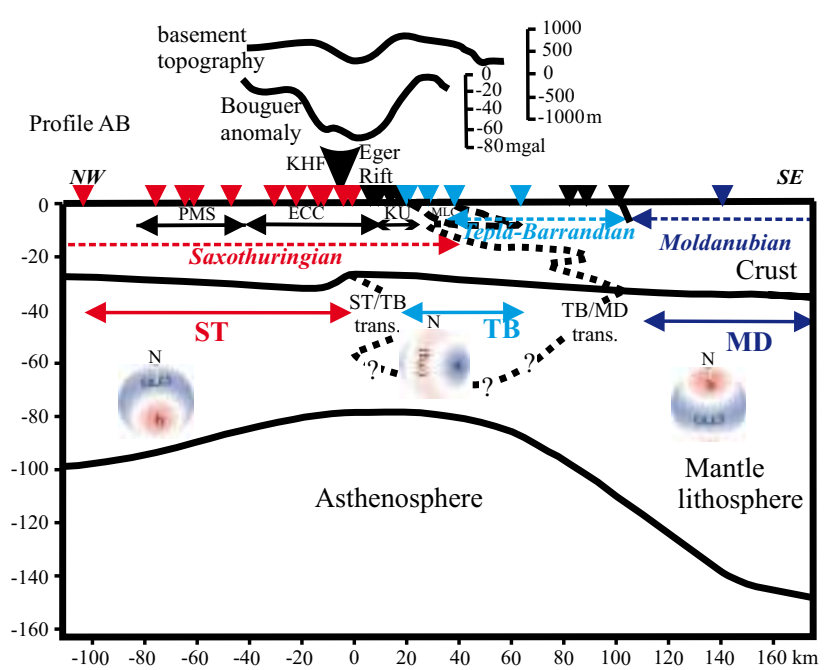




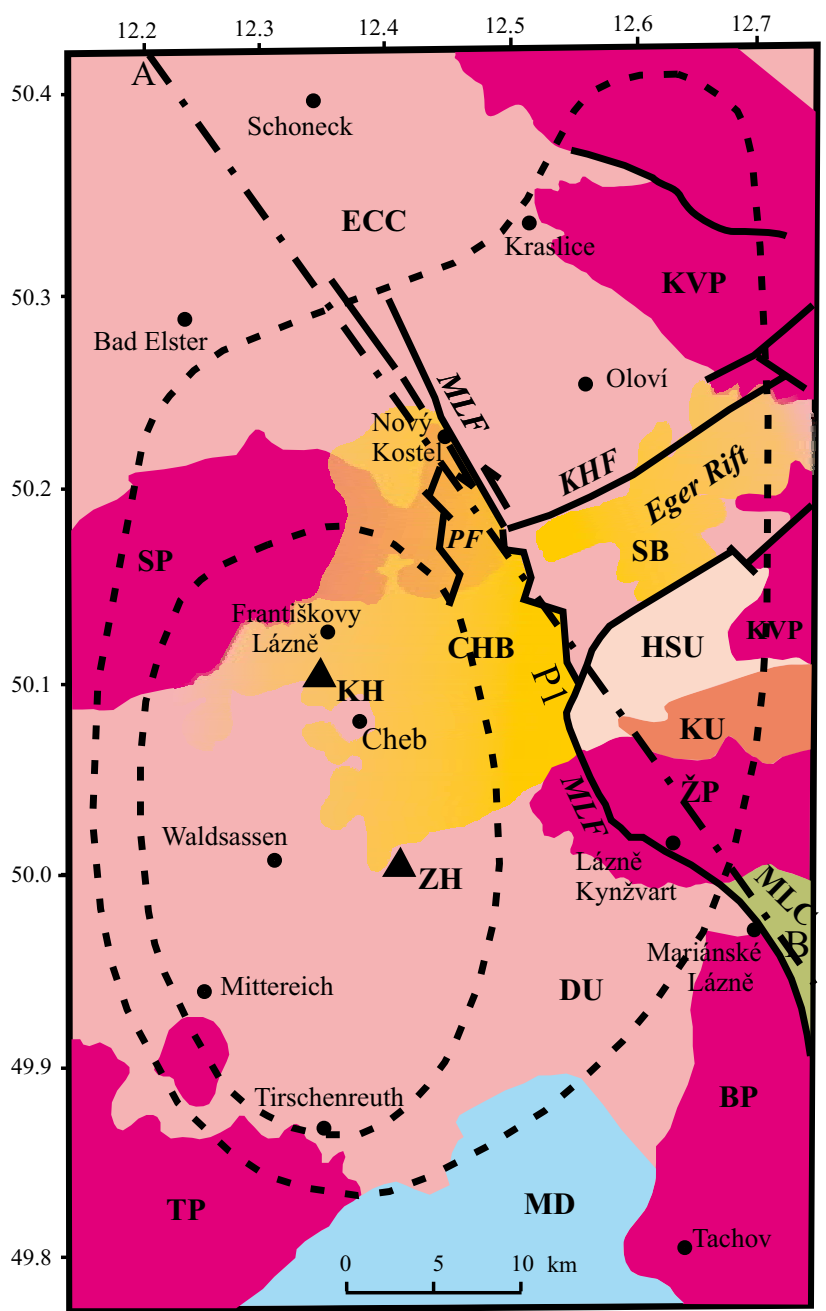

Fig. 6 Geological map of the ST-TB-MD junction simplified from Kachlík (1997), Zulauf et al. (2002), Mlčoch (2003) and Schunk et al. (2005). Saxothuringian: ECC - Erzgebirge (Krušné hory) Crystalline Complex, DU - Dyleň Unit, HSU - Horní Slavkov Unit, KU - Kladská Unit; Teplá-Barrandian: MLC - Mariánské Lázně Complex; MD Moldanubian. Variscan granitoids: SP - Smrčiny (Fichtlgebirge) Pluton, KVP - Karlovy Vary Pluton, ŽP - Žandov Pluton, BP - Bor Pluton, TP - Tirschenreuth Pluton. CHB - Cheb Basin, SB - Sokolov Basin. KHF - Krušné Hory Fault, MLF - Mariánské Lázně Fault, PF - Plesná Fault (Schunk et al. 2005). Quaternary volcanoes: $\mathrm{KH}$ - Komorní hůrka and ZH - Železná hůrka. The dashed contours show the crust thinning to less than $30 \mathrm{~km}$ (outer curve) and to $28 \mathrm{~km}$ (inner curve) beneath the Cheb Basin (Heuer 2006).

continuation of the ER to the south-west, where the rift signatures developed above the ST/MD contact, but without a significant Ohře graben-like structure on the surface. Babuška et al. (2010) suggested that, unlike the sharp contact of the ST and TB mantle lithospheres east of the CHB, the ST/MD mantle junction in NE Bavaria is a complex transition of both units extending to about $150 \mathrm{~km}$ toward the south from their surface boundary (Babuška and Plomerová 2001). Though the ST/MD contact is also marked by lithosphere thinning
(Plomerová et al. 1998), similar to that beneath the ER proper east of the CHB (Fig. 1), the asymmetric graben morphology (e.g., Grygar et al. 2006) did not develop above the broad slanting contact of both units.

A model lithosphere section perpendicular to the western ER shows the observations of lateral changes of the anisotropy patterns, together with major geological features and changes in the surface topography and Bouguer gravity anomalies (Fig. 4). In the regional gravity field, the ST/TB suture is characterized by a strong gradient between the distinctly negative gravity field of the ST and only slightly negative or even positive gravity field of the TB (Plaumann and Švancara 1996). The contact of both units is marked by a chain of local positive gravity anomalies, which start from the MLC and continue to the NE (Šrámek 2001). The crustal structure (Fig. 6) reflects the abrupt change of the mantle fabrics. The area of the TB adjacent to the suture represents a Variscan inclined crustal section (Zulauf et al. 1997). During the Early Viséan ( $\sim 340 \mathrm{Ma})$, a significant vertical uplift of more than $10 \mathrm{~km}$ in the NW segment resulted in the juxtaposition of upper-crustal rocks of the TB unit against lower-crustal rocks of the Ohře Crystalline Complex (Zulauf et al. 2002).

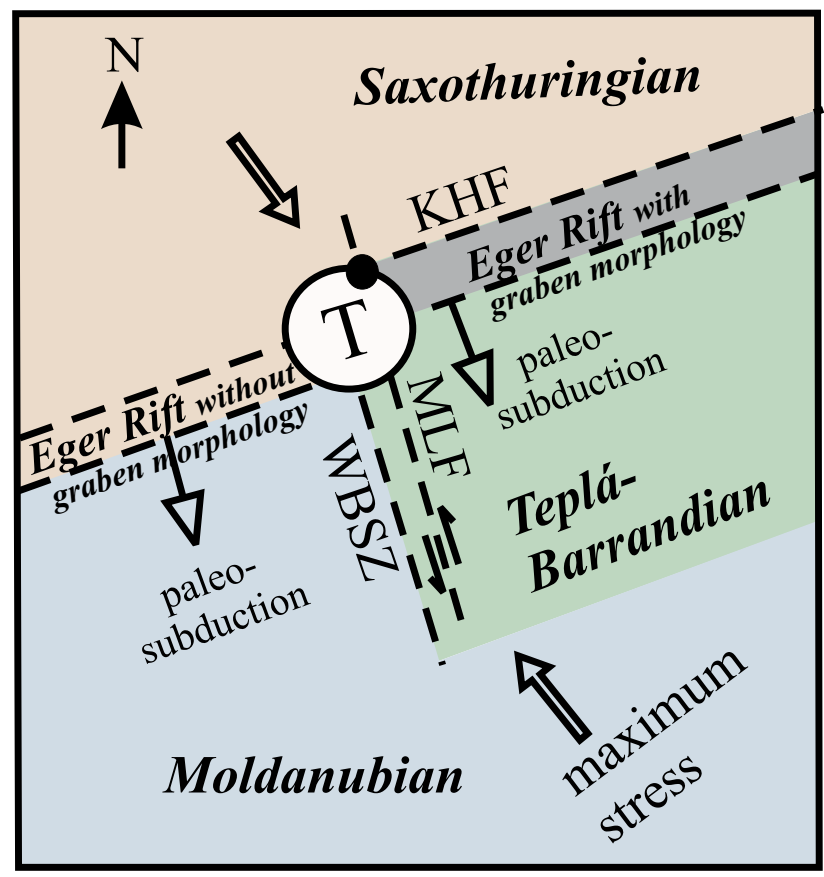

Fig. 7 Tectonic sketch showing a present-day situation of the " $T$ (triple) junction" of the mantle lithosphere domains representing most probably remnants of three microplates assembled during the Variscan orogeny. From the point of geodynamics the junction at the northwest tip of the Teplá-Barrandian microplate is the most active part of the Bohemian Massif with the Nový Kostel swarm area marked by the black dot (see also Fig. 8). Stress orientation in the uppermost crust is according to Müller et al. (1992). For abbreviations see caption to Fig. 6. 
Divergently dipping fabrics of the ST and MD mantle lithospheres were recognized throughout the whole BOHEMA array (Plomerová et al. 2007) and also modelled in the westernmost rim of the BM in Bavaria (Plomerová et al. 1998), where both units juxtapose each other. The most prominent feature of the lithosphere section is the location of the CHB and the western ER above the transition between the ST and TB mantle lithospheres. The "mantle triple junction" has a shape of capital T, with the ST mantle lithosphere to the north and the mantle lithospheres of the MD and TB units to the south-west and south-east from their mantle boundary (WBSZ, Fig. 7) projected into the MLF-KHF intersection on the surface.

\section{Discussion}

\subsection{Mantle control of the Saxothuringian- Teplá-Barrandian microplate boundary deformation}

Our previous results (Plomerová et al. 2005, 2007; Babuška et al. 2008) proved that the TB unit has its own mantle lithosphere though its thickness is probably smaller than that of the ST and MD units. A model of juxtaposition of the three domains of mantle lithosphere, each bearing a consistent fossil olivine fabric, is shown in a schematic block-diagram in Fig. 8. The TB, the best preserved fragment of the Cadomian orogen in central Europe (Franke 2000), probably played a key role in the plate-tectonic development of the region as a median massif between the ST and MD units intervening during the Variscan orogeny from opposite sides (Franke 2006). The mantle boundary between the TB and the ST, and its crustal equivalent rimmed with mantle rocks (Mlčoch 2001), represent a Variscan suture later copied by the ER. Previously Kopecký (1986) suggested that the ER developed by Alpine remobilization of an older heterogeneity in the deep crystalline basement. We also showed that the late Variscan mantle transition between the ST and TB units is characterized by a lithosphere thinning to 80-90 km (Plomerová et al. 1998; Babuška and Plomerová 2001). However, the crystalline basement of the western ER belongs to the ST unit (Tomek et al. 1997; Mlčoch 2003; Mlčoch and Konopásek 2010), which is in allochtonous position above this mantle transition.

It is generally accepted that after a complete subduction of the ST oceanic lithosphere, the process continued by a continental collision accompanied by subduction and a subsequent exhumation at the north-western margin of the TB unit (Babuška et al. 2010). The MLC and its equivalent beneath the Doupovské hory Mts. (Mlčoch 2003), both being thrust over the ST crust, indicate a collision of the two plates with a complicated shape of their margins. Both high-grade metamorphic complexes represent a mixture of $c$. $540 \mathrm{Ma}$ oceanic rocks juxtaposed at depth with lower-crustal rocks of the structurally overlying TB unit (Tomek et al. 1997; Timmermann et al. 2004). We can speculate that the subducting ST microplate was colder and stronger than the overriding TB plate, which was tilted to the SE exposing deeper crustal levels at the ST/TB collision zone (Zulauf et al. 1997). However, in both plates rigid parts of the crust were detached from the mantle, which was probably "welded" in 'crocodile-type' intercalations of both mantle lithospheres.

There are at least three observations indicating the crust/mantle detachment in the western ER. First, it is documented by $\sim 25 \mathrm{~km}$ shift between the ST/TB boundary mapped on the crystalline surface and its mantle counterpart (Plomerová et al. 2007 and Fig. 4). It is interesting to note that Kachlík (1997) estimated a thrust movement of the MLC over the Kladská Unit (KU, Fig. 6) for at least $25 \mathrm{~km}$. The second indication is in the crustal section derived from the 9HR refraction profile (Tomek et al. 1997; Švancara and Chlupáčová 1997, also Fig. 8), where the ST crust is thrust beneath the TB crust to a distance of about $100 \mathrm{~km}$, southward of the northern rim of the MLC. Third, detachments of rigid pieces of the upper crust are also reflected in the thin-skinned tectonics documented by the Zone of Erbendorf-Vohenstrauss (ZEV). Tectonic, petrological and geochronological features of the ZEV are directly comparable with those of the TB unit (O'Brien 1997) situated about $50 \mathrm{~km}$ eastward.

Laminated lower crust revealed by refraction/reflection profiling in the western BM, and mostly in its ST part (DEKORP Research Group 1994; Hrubcová et al. 2005), supports such detachment along a ductile zone in the lower crust, observed also in several west European regions (Müller et al. 1997). The latter authors suggest that a weak constant shear stress develops in the lower crust due to a differential velocity of the motion between the brittle upper crust and the mantle lithosphere. The model of the crust, which was decoupled from the mantle, implies to some extent an independent tectonics of both parts of the present-day lithosphere of the western BM. On the other hand, the present geodynamic activity indicates that both layers intimately link via reactivated Variscan boundaries.

The periodic occurrence of earthquake swarms (Horálek and Fischer 2008) and neotectonic crustal movements (Bankwitz et al. 2003; Schunk et al. 2005) indicate that the crust deformation continues even nowadays. It is interesting to note that almost all earthquakes in the western BM occur within the ST crust (Figs 6 and 8 ) and are located within a small focal area near Nový Kostel (Babuška et al. 2007). About 90 \% of seismic energy estimated for a period 1991-1999 by Horálek et al. 


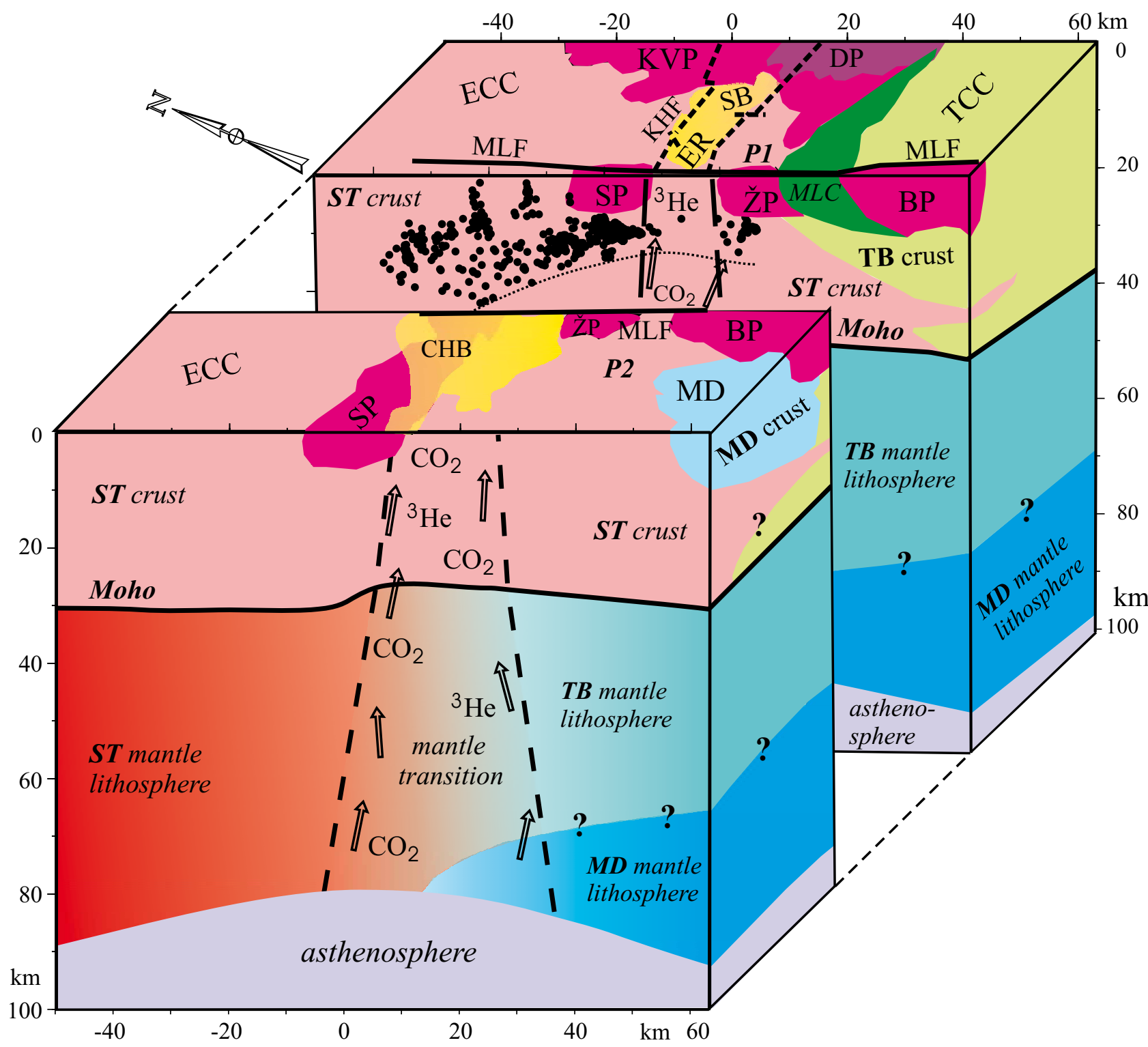

Fig. 8 Schematic cartoon showing the near surface geology (see Fig. 6 for explanation of symbols) and deep tectonics of the western Bohemian Massif. Model structure of the mantle lithosphere is based on observations of seismic anisotropy (Plomerová et al. 2007; Babuška et al. 2008). The lateral transition in the mantle indicates the boundary zone between the Saxothuringian (ST) and Teplá-Barrandian (TB) mantle lithospheres. Thicknesses and shapes of the MLC, SP and ŽP are according to Tomek et al. (1997), Hecht et al. (1997) and Blecha et al. (2009). Black dots are earthquake foci according to Fischer and Horálek (2003), the brittle-ductile transition in the crust (the dashed curve) follows the deepest foci of the earthquake swarms. Note that the earthquake foci are located mainly in the Ohře (Eger) Rift flanks and only in the ST crust, which is thrust over the ST/TB mantle transition and under the TB crust.

(2000) for the whole seismically active part of the Vogtland/western BM was released in the Nový Kostel area situated above the ST/TB mantle transition (Fig. 6), near the crossing of the KHF and the MLF. These faults represent the crustal expression of the ST/TB mantle suture and the NNW oriented MD/TB mantle boundary (Fig. 4). The long-term crustal deformation of the area is also indicated by a higher metamorphic grade of the block situated eastward of Nový Kostel (uplifted by at least $1 \mathrm{~km}$, J.
Fiala, pers. comm. 2005). Similarly, major emanations of mantle-derived fluids $\left(\mathrm{CO}_{2}\right.$ and helium, Bräuer et al. 2005; Babuška and Plomerová 2008) concentrate within the CHB situated above the mantle T-junction (Fig. 7). Therefore, we can assume that the mantle boundaries of the microplates, assembled during the Variscan orogeny and rejuvenated in the Cenozoic, most probably control the present-day geodynamic activity in the region, regardless the ST crust thrust over. 


\subsection{Close spatial relationship between mantle sutures and magmatism}

\subsubsection{Variscan magmatism}

In this part we focus on locations and orientations of granitoid massifs in the western BM in relation to the previously described mantle boundaries. Petford et al. (2000) studied 3D geometries of granitic plutons and concluded that they mostly appear as flat-lying to open funnel-shaped structures with central or marginal feeder zones with a small number of conduits. This is also true for the major body of the Late-Variscan Smrčiny (Fichtelgebirge) Pluton (SP in Fig. 6), which was emplaced along the WSW continuation of the Krušné Hory Fault (KHF) above the ST/MD mantle suture and from a feeder channel situated near the KHF/MLF crossing (Hecht et al. 1997), located directly above the mantle T-junction (Figs. 6 and 7). Also the Žandov Pluton (ŽP) and the Bor Pluton (BP) seem to be closely related to the MLF and to the West-Bohemian Shear Zone (WBSZ, see also Siebel et al. 1999; Zulauf et al. 2002), where we map the mantle boundary between the TB and MD units (Fig. 4). We expect that several seismic stations newly installed in Bavaria above the TB/MD mantle junction will provide additional data for constraining a course of this mantle boundary and help to clarify a relation of both parallel fault zones (WBSZ and MLF).

Blecha et al. (2009) examined from gravity data the shape of the Late-Variscan Karlovy Vary Pluton (KVP) and of the Žandov Pluton, called by the authors as the Lesný-Lysina (Kynžvart) Massif, separated from the KVP. Such separation can be explained by different ways of magma supplies. The ŽP is located near the MLF and the mantle T-junction, which may have served as ascent paths for granitic magmas. On the other hand, Blecha et al. (2009) deduced from the elongation of the outcropping granite bodies of the KVP, that magma conduits may have been identical to, or parallel with, the Jáchymov Fault, paralleling the MLF at about $50 \mathrm{~km}$ eastward, and in the southern part of the KVP with the ER. By analogy with the KVP, Weinberg et al. (2004) pointed out that 'en cornu' shaped plutons in north-eastern Brazil were particularly emplaced where regional-scale shear zones intersect major lithological boundaries. Our suggestion of the mantle boundaries as major magma feeders is in accord with the models of emplacement of granite plutons (Petford et al. 2000; Cruden 2006; Blecha et al. 2009) by successive additions of sheet-like intrusions in repeated magma pulses.

Though we do not discuss the Krušné hory granite Batholith which is outside the area covered by the present study, it is worth mentioning that Kováríková et al. (2007) pointed out an importance of the mantle compo- nent in the intrusions forming this batholith, as well as a significant role of mantle-derived mafic magmas in heating of the sources of granitic melts. Also Siebel et al. (2003) found that mantle-related magmatism in NE Bavaria postdated the final convergence stage of the Variscan orogen (see also Finger et al. 2009).

\subsubsection{Alkaline magmatism}

Because the teleseismic tomography down to $250 \mathrm{~km}$ did not image any distinct heterogeneity which could be interpreted as a narrow mantle plume (Plomerová et al. 2007), the asthenosphere became a major candidate as a potential source of the Cenozoic volcanism in the western BM. This has been confirmed by Haase and Renno (2008) who observed no systematic changes in compositions of Cenozoic lavas across the lithospheric boundaries in the area of the western ER and concluded that the asthenosphere was the most common magma source. Wilson and Downes (2006) suggested that in general, melt generation in the asthenosphere and at the base of the lithosphere is a consequence of decompression partial melting, triggered by upwelling of the lithosphere-asthenosphere transition. In the western ER both the lithosphere (Plomerová et al. 1998; Plomerová and Babuška in press) and the crust (Geissler et al. 2005; Heuer 2006) are thinned to about $80 \mathrm{~km}$ and $27 \mathrm{~km}$, respectively.

The asthenospheric origin of melts also indicates that the flux channels are obviously interconnected through the whole lithosphere. For alkaline magmatism and the present-day "post-volcanic" phenomena in the western $\mathrm{BM}$, permissive release of a heat and materials flux from the asthenosphere is the essential factor. The flux is probably easily channelled to relatively narrow zones along the boundaries of mantle lithosphere. The largest flux of the mantle $\mathrm{CO}_{2}$ is observed in the Cheb Basin directly above the mantle T-junction (Babuška and Plomerová 2008 and Fig. 8).

Two Quaternary volcanoes - Komorní hůrka and Železná hůrka ( $\mathrm{KH}$ and $\mathrm{ZH}$ in Fig. 6), which are situated above the T-junction of the mantle lithospheres, are located along the mantle boundary between the TB and MD expressed on the surface by the WBSZ. Location of the volcanoes suggests that the junction was a major zone of weakness providing open channels for ascending magmas (Babuška and Plomerová 2008). Also in the French Massif Central a mantle suture, hidden beneath an allochtonous crust and reactivated during the Cenozoic extension of the thinned lithosphere, provided a space for major volcanism (Babuška et al. 2002).

In a broader European context, Wilson and Downes (2006) suggested that boundaries between east-west trending terranes (Rhenohercynian, Saxothuringian, Moldanubian) may be regions of anomalously thin, irregular 
or weak lithosphere. Such deep, laterally persistent fault zones appear to have exerted a significant control on the location of subsequent Cenozoic magmatism, possibly acting as pathways for magma ascent through the lithosphere.

\subsection{Deep-seated predisposition of sedimentary basins}

Location of sedimentary basins of the western ER also indicates a possible influence of the deep lithosphere structure on basin formation (Babuška et al. in press). We suggest that a better knowledge of the mantle structure can contribute to the understanding of why a basin originated at a particular place and developed in a certain way.

The asymmetric Cheb Basin (CHB), which is superimposed on the western limit of the graben part of the ER (Figs 4 and 6), formed during the Pliocene and early Pleistocene (4.5-1.5 Ma) (Špičáková et al. 2000) by reactivation of the intersecting fracture systems of the ENE trending Krušné Hory Fault (KHF) and the NNW trending Mariánské Lázně Fault (MLF). This intersection is above the T-junction of the ST, TB and MD mantle lithospheres (Plomerová et al. 2007). The eastern margin of the CHB is defined by the northern part of the MLF along which the depot centre of the basin developed. The CHB belongs to the ER, but it lies outside the morphologically distinct graben structure of the rift (Fig. 6). Babuška et al. (2010) suggested that this is because the graben has developed above the mantle suture between the ST and TB units, while the CHB position was predestined by the crustal and lithosphere thinning above the "triple junction" of the ST/TB/MD mantle lithospheres. The NNW striking WBSZ, as a deep boundary between the TB and MD mantle lithospheres in the western BM (Plomerová et al. 2007), and the sub-parallel MLF probably played a very important role in the CHB development. The MLF forms the ENE limit of the CHB, but it finds no morphological expression of its zigzag course above the ST-TB mantle transition zone. On the other hand, the MLF is straight with escarpments expressed in 200-400 $\mathrm{m}$ heights above the flanks of this transition (Schunk et al. 2005 and Fig. 6), i.e., above the rigid rims of the ST and TB mantle lithospheres.

\section{Conclusions}

Boundaries of the mantle lithosphere domains with consistent fabrics play important role in the crust architecture and the present-day geodynamic activity. This paper reviews most of our research on the deep lithosphere structure in the western part of the Bohemian Massif (BM).

- Mapping the three-dimensional seismic anisotropy of the mantle lithosphere from anisotropic parameters of teleseismic body waves, shear-wave splitting parameters and directional terms of $\mathrm{P}$ residuals, identified three mantle domains in the western BM. Their boundaries are delimited by a change in orientation of seismic anisotropy, consistent within the individual domains. The observed anisotropy reflects a fossil olivine preferred orientation which most probably formed prior to the Variscan assembly of the originally separated microplates - the Saxothuringian (ST), Moldanubian (MD) and Teplá-Barrandian (TB).

- The mantle boundaries are locally shifted from their surface counterparts indicating thus a crust/mantle detachment. The part of the Ohře (Eger) Rift (ER) characterized by the graben morphology developed above the steep lithosphere-scale Variscan suture between the ST and TB mantle domains. Unlike this sharp and steep suture, the ST/MD mantle contact in NE Bavaria is an inclined southward dipping transition. This is probably a reason why the typical graben morphology did not develop in the SW continuation of the ER, though some Cenozoic sediments and volcanic rocks indicate a continuation of the rift structure south-west of the Cheb Basin (CHB).

- The most distinct effects of the deep lithosphere on the near surface tectonics seem to be found above the Tshape mantle 'triple junction' separating the ST mantle lithosphere from the MD and TB mantle lithospheres situated to the southwest and the southeast, respectively. Due to a Cenozoic rejuvenation of this junction, the area is from the point of geodynamics the most active part of the BM.

- Architecture of the mantle lithosphere probably plays important role also in the location of the late-orogenic granitoid massifs. The boundaries of the accreted lithospheric blocks may have acted as magma feeders providing successive additions of sheet-like intrusions in repeated magma pulses. The feeder of the major part of the Smrčiny (Fichtelgebirge) Pluton located at the crossing of the Krušné Hory and Mariánské Lázně faults above the mantle T-junction can serve as an example.

- The seismic tomography did not reveal a narrow plume in the upper mantle as a possible source of the Cenozoic volcanism in the region. Therefore, the asthenosphere upwelling in the western ER is the most probable source of magmas which may be channelled to the surface along partly open boundaries of the lithospheric blocks. The two Quaternary volcanoes (Komorní hůrka and Železná hůrka; KH, ZH in Fig. 6) and the major present-day emanations of large volumes of mantle gases are located above the mantle T-junction.

- Though the Cheb Basin is situated within the ST crust, it developed above the mantle T-junction, outside the morphologically distinct ER graben. 
- We have suggested that the sublithospheric mantle of the western BM could have acted as major provider for heat and partial melts tapped by boundaries of the lithospheric microplates. The mantle boundaries of individual blocks represent weakened zones and partly open conduits into the crust and to the surface. Therefore, several phenomena often vaguely described as intraplate, like the magmatism, volcanism and earthquakes, can be directly linked with healed up paleoplate boundaries. This finding may also apply to other continental regions.

Acknowledgements. We thank Čestmír Tomek and an anonymous second reviewer for their constructive comments and suggestions how to improve the original manuscript. The research was supported by the Grant Agency of the Czech Republic project 205/07/1088 and by grant No. IAA300120709 of the Grant Agency of the Czech Academy of Sciences.

\section{References}

BABUŠKa V, CARA M (1991) Seismic anisotropy in the Earth. Kluwer Academic Publishers, Dordrecht, pp 1-217

BABušKa V, Plomerová J (1992) The lithosphere in central Europe - seismological and petrological aspects. Tectonophysics 207: 141-163

BABušKa V, Plomerová J (2001) Subcrustal lithosphere around the Saxothuringian-Moldanubian Suture Zone - a model derived from anisotropy of seismic wave velocities. Tectonophysics 332: 185-199

BabušKa V, Plomerová J (2006) European mantle lithosphere assembled from rigid microplates with inherited seismic anisotropy. Phys Earth Planet Inter 158: 264-280

BabušKa V, Plomerová J (2008) Control of paths of Quaternary volcanic products in western Bohemian Massif by rejuvenated Variscan triple junction of ancient microplates. Stud Geophys Geod 52: 607-629

Babuška V, Plomerová J, Vecsey L, Granet M, Achauer U (2002) Seismic anisotropy of the French Massif Central and predisposition of Cenozoic rifting and volcanism by Variscan suture hidden in the mantle lithosphere. Tectonics 21: 11-1-11-20

BabušKa V, Plomerová J, Bohema Working Group (2003) BOHEMA seismic experiment: search for an active magmatic source in the deep lithosphere in central Europe. EOS, Trans AGU 84: 409-417

BabušKa V, Plomerová J, Fischer T (2007) Intraplate seismicity in the western Bohemian Massif (central Europe): a possible correlation with a paleoplate junction. J Geodyn 44: 149-159

Babuška V, Plomerová J, Vecsey L (2008) Mantle fabric of western Bohemian Massif (central Europe) constrained by $3 \mathrm{D}$ seismic $\mathrm{P}$ and $\mathrm{S}$ anisotropy. Tectonophysics 462 : 149-163

Babuška V, Fiala J, Plomerová J (2010) Bottom to top lithosphere structure and evolution of western Eger Rift (central Europe). Int J Earth Sci 99: 891-907

Babuš́a V, Plomerová J, Vecsey L (in press) Links between the structure of the mantle lithosphere and morphology of the Cheb Basin (Eger Rift, central Europe). Int J Earth Sci; DOI 10.1007/s00531-010-0531-4

BAILEY DK, Wooley AR (1999) Episodic rift magmatism: the need for a new paradigm in global dynamics. Geolines 9: $15-20$

Bankwitz P, Schneider G, Kämpf H, Bankwitz E (2003) Structural characteristics of epicentral areas in Central Europe: study case Cheb Basin (Czech Republic). J Geodyn 35: 5-32

Ben Ismail W, Mainprice D (1998) An olivine fabric database: an overview of upper mantle fabrics and seismic anisotropy. Tectonophysics 296: 145-157

Blecha V, Štemprok M, Fischer T (2009) Geological interpretation of gravity profiles through the Karlovy Vary Granite Massif (Czech Republic). Stud Geophys Geod 53: $295-314$

Bräuer K, Kämpf H, Niedermann S, Strauch G (2005) Evidence for ascending upper mantle-derived melt beneath the Cheb Basin, central Europe. Geoph Res Lett 32: L08303; DOI 10.1929/2004GL022205

СнÁ́ J, STRÁNíK Z, EliÁš M (2007) Geological map of the Czech Republic 1:500 000. Czech Geological Survey, Prague

CRUDEN AR (2006) Emplacement and growth of plutons: implications for rates of melting and mass transfer in continental crust. In: Brown M, Rushmer T (eds) Evolution and Differentiation of the Continental Crust. Cambridge University Press, pp 455-519

DEKORP Research Group (1994) The deep reflection seismic profiles DEKORP 3/MVE-90. Z geol Wiss 22: 623-684

Finger F, Gerdes A, René M, Riegler G (2009) The SaxoDanubian Granite Belt: magmatic response to postcollisional delamination of mantle lithosphere below the south-western sector of the Bohemian Massif (Variscan orogen). Geol Carpath 60: 205-212

Fischer T, HorÁlek J (2003) Space-time distribution of earthquake swarms in the principal focal zone of the NW Bohemia/Vogtland seismoactive region: period 1985-2001. J Geodyn 35:125-144

Fouch MJ, Rondenay S (2006) Seismic anisotropy beneath stable continental interiors. Phys Earth Planet Inter 158: 292-320

Franke W (2000) The mid-European segment of the Variscides: tectonostratigraphic units, terrane boundaries and plate tectonic evolution. In: Franke W, HaAK V, OnCKeN O, TANNer D (eds) Orogenic Processes: Quantification 
and Modelling in the Variscan Belt. Geological Society London Special Publications 179: 35-61

Franke W (2006) The Variscan orogen in Central Europe: construction and collapse. In: GeE DG, StePHenson RA (eds) European Lithosphere Dynamics. Geological Society London Memoirs 32: 333-343

Franke W, Dallmeyer Rd, Weber K (1995) Geodynamic evolution. In: Dallmeyer RD, Franke W, Weber K (eds) Pre-Permian Geology of Central and Eastern Europe. Springer-Verlag, Berlin, pp 579-593

Geissler WH, Kämpf H, Kind R, Bräuer K, Klinge K, Plenefisch T, Horálek J, Zední J, Nehybka V (2005) Seismic structure and location of a $\mathrm{CO}_{2}$ source in the upper mantle of the western Eger (Ohře) Rift, central Europe. Tectonics 24: TC5001; DOI 10.1029/2004TC001672

Geissler WH, Sodoudi F, Kind R (2010) Thickness of the European lithosphere as seen by $\mathrm{S}$ receiver functions. Geophys J Int 181: 604-634

Grad M, Guterch A, Mazur S, Keller GR, ŠpičÁK A, HRubCovÁ P, GeIsSLER WH (2008) Lithospheric structure of the Bohemian Massif and adjacent Variscan belt in central Europe based on profile S01 from the SUDETES 2003 experiment. J Geophys Res 113: B10304; DOI 10.1029/2007JB005497

Granet M, Wilson M, Achauer U (1995) Imaging a mantle plume beneath the Massif Central (France). Earth Planet Sci Lett 17: 1109-1112

Grygar R, Grmela A, Jelínek J, Pöpperl J, Galek R (2006) Tectonic setting of Sokolov Basin in relation to prediction of thermal water discharge zones. Geolines 20: 44-45

HaAse KM, Renno AD (2008) Variation of magma generation and mantle sources during continental rifting observed in Cenozoic lavas from the Eger Rift, Central Europe. Chem Geol 257: 192-202

Hecht L, Vigneresse JL, Morteani G (1997) Constrains on the origin of zonation of the granite complexes of the Fichtelgebirge (Germany and Czech Republic). Evidence from gravity and geochemical study. Geol Rundsch 86: 93-109

Heuer B (2006) Lithospheric and upper mantle structure beneath the western Bohemian Massif obtained from teleseismic $\mathrm{P}$ and $\mathrm{S}$ receiver functions. Scientific Technical Report STR06/12, GeoForschungsZentrum Potsdam, ISSN 1610-0956, pp 1-149

HoRÁLEK J, FisCher T (2008) Role of crustal fluids in triggering the West Bohemia/Vogtland earthquake swarms: just what we know (a review). Stud Geophys Geod 52: 455-478

Horálek J, Fischer T, BoušKová A, JedličKa P (2000) The western Bohemia/Vogtland region in the light of the WEBNET network. Stud Geophys Geod 44: 107-125

Hrubcová P, Sroda P, Špičák A, Guterch A, Grad M, Keller GR, Brueckl E, Thybo H (2005) Crustal and uppermost mantle structure of the Bohemian Massif based on CELEBRATION 2000 data. J Geophys Res 110, B11305; DOI 101029/2004JB003080

JINDŘICH V (1971) New views in tectonic significance of platform sediments in the Bohemian Massif, Czechoslovakia. Geol Soc Am Bull 82: 763-768

KaCHLík V (1997) The Kladská Unit. In: VRÁNA S, ŠTĚDRÁ V (eds) Geological Model of Western Bohemia Related to the KTB Borehole in Germany. Sbor geol věd, Geol 47: 70-80

Kämpf H, Peterek A, Rohrmüller J, Kümpel HJ, Geissler WH (2005) The KTB Deep Crustal Laboratory and the western Eger Graben. In: Косн R, RöHLING HG (eds) GeoErlangen 2005 System Earth - Biosphere Coupling, Regional Geology of Central Europe, Exkursionsführer. Schriftreihe Dt Ges Geowiss 40: 37-107

KennetT BLN (1991) IASPEI 1991, Seismological Tables. Research School of Earth Science, Australian National University, Canberra, pp 1-167

KOPECKÝ L (1978) Neoidic taphrogenic evolution and young alkaline volcanism of the Bohemian Massif. Sbor geol věd, Geol 31: 91-107

KopeckÝ L (1986) Geological development and block structure of the Cenozoic Ohře Rift (Czechoslovakia). In: AldRich JR MJ, LAughlin AW (eds) Proceedings of the $6^{\text {th }}$ International Conference on Basement Tectonics, Santa Fe, USA, Sept. 16-20, 1985. International Basement Tectonics Association, Salt Lake City, pp 111-124

KováŘíková P, Siebel W, Jelínek E, ŠTemprok M, Kachlík V, Holub FV, Blecha V (2007) Petrology, geochemistry and zircon age for redwitzite at Abertamy, NW Bohemian Massif (Czech Republic): tracing the mantle component in Late Variscan intrusions. Chem Erde 67: 151-174

Krawczyk CM, Stein E, Choi S, Oettinger G, Schuster K, Götze HJ, Haak V, Prodehl C, Schulze A (2000) Geophysical constraints on exhumation mechanisms of high-pressure rocks: the Saxo-Thuringian case between the Franconian Line and Elbe Zone. In: Franke W, HaAK V, Oncken O, TANner D (eds) Orogenic Processes: Quantification and Modelling in the Variscan Belt. Geological Society London Special Publications 179: 303-322

MLČOCH B ed (2001) Investigation of Crystalline Formations in Deep Basement Structures of the Doupov Complex and its Broad Surroundings. Unpublished final Report, Czech Geological Survey, Prague, pp 1-121 (in Czech) MLČOCH B (2003) Character of the contact between the Saxothuringian and Teplá-Barrandian unit. Geolines 16: 75

MLČoch B, KonopáseK J (2010) Pre-Late Carboniferous geology along the contact of the Saxothuringian and Teplá-Barrandian zones in the area covered by younger sediments and volcanics (western Bohemian Massif, Czech Republic). J Geosci 55: 81-94

Müller B, Wehrle V, Zeyen H, Fuchs K (1997) Short-scale variations of tectonic regimes in the western European stress province north of the Alps and Pyrenees. Tectonophysics 275: 199-219 
O'Brien JP, Duyster J, Grauert B, Schreyer W, Stöckert B, Weber K (1997) Crustal evolution of the KTB drill site: from oldest relics to the late Hercynian granites. J Geophys Res 102: B8, 18 203-18 220

Petford N, Cruden AR, McCaffrey KJW, Vigneresse JL (2000) Granite magma formation, transport and emplacement in the Earth's crust. Nature 408: 669-673

Plaumann S, Švancara J (1996) Tschechisch-deutsche Schwerekarte 1:500.000 um Erzgebirge und Böhmerwald (Krušné hory, Český les). Unpublished manuscript, Hannover/Brno

Plomerová J, Babuš́a V (in press) Long memory of mantle lithosphere fabric - European LAB constrained from seismic anisotropy. Lithos; DOI 10.1016/j.lithos.2010.01.008

Plomerová J, Babuška V, Š́́lený J, Horálek J (1998) Seismic anisotropy and velocity variations in the mantle beneath the Saxothuringicum-Moldanubicum contact in central Europe. Pure Appl Geophys 151: 365-394

Plomerová J, Vecsey L, Babuška V, Granet M, Achauer U (2005) Passive seismic experiment MOSAIC - a pilot study of mantle lithosphere anisotropy of the Bohemian Massif. Stud Geophys Geod 49: 541-560

Plomerová J, Achauer U, Babuška V, Vecsey L, Bohema WorkING Group (2007) Upper mantle beneath the Eger Rift (Central Europe): plume or asthenosphere upwelling? Geophys J Int 169: 675-682

Prodehl C, Müller S, Haak V (1995) The European Cenozoic rift system. In: Olsen KH (ed) Continental Rifts: Evolution, Structure, Tectonics. Elsevier, Amsterdam, pp 133-212

RitTer JRR, JoRdAn M, CRistensen UR, Achauer U (2001) A mantle plume below the Eifel volcanic fields, Germany. Earth Planet Sci Lett 186: 7-14

Savage MK (1999) Seismic anisotropy and mantle deformation: what have we learned from shear wave splitting? Rev. Geophysics 37: 65-106

Schunk R, Peterek A, Reuther CD (2005) Second day: active processes of the western Eger Graben system, Stop 6a-c. In: Kämpf H, Peterek A, Rohrmüller J, Kümpel HJ, Geissler W (eds) The KTB Deep Crustal Laboratory and the Western Eger Graben. Schriftreihe Dt Ges Geowiss 40: 66-71

Siebel W, Breiter K, Wendt I, HöHndorf A, Henjes-Kunst F, ReNÉ M (1999) Petrogenesis of contrasting granitoid plutons in western Bohemia (Czech Republic). Mineral Petrol 65: 207-235

Siebel W, Chen F, Satir M (2003) Late-Variscan magmatism revisited: new implications for $\mathrm{Pb}$-evaporation zircon ages on the emplacement of redwitzites and granites in NE Bavaria. Int J Earth Sci 92: 36-53

Š́́lenÝ J, Plomerová J (1996) Inversion of shear-wave splitting parameters to retrieve three-dimensional orientation of anisotropy in continental lithosphere. Phys Earth Planet Inter 95: 277-292
ŠPIČÁKová L, Ulě̃nÝ D, Koudelková G (2000) Tectonosedimentary evolution of the Cheb Basin (NW Bohemia, Czech Republic) between Late Oligocene and Pliocene: a preliminary note. Stud Geoph Geod 44: 556-580

ŠrÁmeK J (2001) Gravimetry. In: MLČoch B (ed) Investigation of Crystalline Formations in Deep Basement Structures of the Doupov Complex and Broader Surroundings. Czech Geological Survey, Prague, pp 1-10 (in Czech)

Švancara J, Chlupáčová M (1997) Density model of geological structure along the profile 9HR. In: VRÁNA $S$, ŠTĚDRÁ V (eds) Geological Model of Western Bohemia Related to the KTB Borehole in Germany. Sbor geol věd, Geol 47: 32-36

Švancara J, Gnojek I, HubatKa F, DědÁČEK K (2000) Geophysical field pattern in the west Bohemian geodynamic active area. Stud Geoph Geod 44: 307-326

Timmermann H, Štědrá V, Gerdes A, Noble SR, Parrish RR, DöRR W (2004) The problem of dating high-pressure metamorphism: a U-Pb isotope and geochemical study of eclogites and related rocks of the Mariánské Lázně Complex, Czech Republic. J Petrol 45: 1311-1338

Tomek Č, Dvoř́́ková V, VRÁNa S (1997) Geological interpretation of the 9HR and 503M seismic profiles in western Bohemia. In: VRÁNA S, ŠTĚDRÁ V (eds) Geological Model of Western Bohemia Related to the KTB Borehole in Germany. Sbor geol věd, Geol 47: 43-50

Ulrych J, Cajz V, Pivec E, Novák JK, NekovaŘík Č (2000) Cenozoic intraplate alkaline volcanism of western Bohemia. Stud Geoph Geod 44: 346-351

Vecsey L, Plomerová J, Babuška V (2008) Shear-wave splitting measurements - problems and solutions. Tectonophysics 462: 178-196

Weinberg RF, Sial AN, Mariano G (2004) Close spatial relationship between plutons and shear zones. Geology 32: $377-380$

Weinlich FH, Bräuer K, KämpF H, Strauch G, Tesar̆ J, Weise SM (1999) An active subcontinental mantle volatile system in the western Eger Rift, Central Europe: gas flux, isotopic ( $\mathrm{He}, \mathrm{C}$, and $\mathrm{N})$ and compositional fingerprints. Geochim Cosmochim Acta 63: 3653-3671

WiLSON M, Downes H (2006) Tertiary-Quaternary intraplate magmatism in Europe and its relationship to mantle dynamics. In: GeE DG, StePhenson RA (eds) European Lithosphere Dynamics. Geological Society London Memoirs 32: 147-166

Ziegler PA (1992) European Cenozoic rift system. Tectonophysics 208: 91-111

Zulauf G (1997) Von der Anchizone bis zur Eklogitfazies Angekippte Krustenprofile als Folge der cadomischen und variscischen Orogenese im Teplá-Barrandium (Böhmische Masse). Geotekt Forsch 89: 1-302

Zulauf G, Dörr W, Fiala J, Vejnar Z (1997) Late Cadomian crustal tilting and Cambrian transtension in the Teplá- 
Barrandian unit (Bohemian Massif, Central European Variscides). Geol Rundsch 86: 571-584

Zulauf G, Buess C, Dörr W, Vejnar Z (2002) $10 \mathrm{~km}$ minimum throw along the West Bohemian shear zone: evidence for dramatic crustal thickening and high topography in the Bohemian Massif (European Variscides). Int J Earth Sci 91: 850-864 